\title{
Compatibility and initial development of grapevines 'BRS Magna' grafted on different rootstocks
}

\section{Chaiane Renata Grigolo ${ }^{1}$ (c) Idemir Citadin ${ }^{1 *}$ () Nelson Pires Feldberg ${ }^{2}$ (c) Silvia Scariotto ${ }^{1}$ (c) Rafael Henrique Pertille ${ }^{1}$ [D Ester Provensi Santos ${ }^{1}$ Kelvin Cristhian Campos Takeshita ${ }^{1}$}

${ }^{1}$ Universidade Tecnológica Federal do Paraná (UTFPR), 85503-390, Pato Branco, PR, Brasil. E-mail:idemir@utfpr.edu.br. "Corresponding author. ${ }^{2}$ Empresa Brasileira de Pesquisa Agropecuária (EMBRAPA), Canoinhas, SC, Brasil.

ABSTRACT: Rootstocks are widely used in viticulture due to their resistance to biotic and abiotic stress. Additionally, rootstocks can affect vine growth and fruit quality. This study evaluated the compatibility and initial developmental of the 'BRS Magna' grafted on different rootstocks The wedge graft technique on woody cuttings was utilized. The percentage of survival ranged from 0\% ('VR043-43') to 98.33\% ('101-14 MGT'), and the rootstock were grouped into three distinct groups. 'IAC 313 Tropical' and 'SO4' rootstocks were those ones with the highest vigor in relation to initial shoot growth. However, 'IAC 572 Jales', 'Harmony', '3309 Couderc' and 'Gravesac' had the best balance between initial shoot growth and root development. The 'BRS Magna' when grafted on rootstocks 'IAC 313 Tropical', 'SO4' and '101-14 $M G T$ ' showed the highest initial development rates, while when grafted on 'R99', 'R110' and '420A', it showed the lowest initial development. Key words: Vitis sp., seedling production, grafting.

\section{Compatibilidade e desenvolvimento inicial de videiras 'BRS Magna' enxertada em diferentes porta-enxertos}

\begin{abstract}
RESUMO: Os porta-enxertos são amplamente utilizados na viticultura devido à sua resistência aos estresses biótico e abiótico. Além disso, os porta-enxertos podem afetar o crescimento da videira e a qualidade dos frutos. O objetivo deste estudo foi avaliar a compatibilidade e o desenvolvimento inicial de videiras 'BRS Magna' enxertada em diferentes porta-enxertos. A técnica de enxertia em fenda foi utilizada. A porcentagem de sobrevivência variou de 0\% (VR043-43) a 98,33\% (101-14 MGT) e os porta-enxertos foram agrupados em três grupos distintos. Os porta-enxertos 'IAC 313 Tropical'e 'SO4'foram os de maior vigor em relação ao crescimento inicial da parte aérea. Já 'IAC 572 Jales', 'Harmony', '3309 Couderc'e 'Gravesac' tiveram o melhor equilíbrio entre o crescimento inicial da parte aérea e o desenvolvimento das raizes. 'BRS Magna' quando enxertada nos porta-enxertos 'IAC 313 Tropical', 'SO4'e '101-14 MGT' apresentou as maiores taxas de desenvolvimento inicial, enquanto que, quando enxertada em 'R99', 'R110'e '420A', apresentou os menores valores iniciais de desenvolvimento. Palavras-chave: Vitis sp., produção de mudas, enxertia.
\end{abstract}

Brazilian winemaking has stood out in the last years for its social and economic importance in the generation of income and employment (ZANUS, 2015). Grape production in Brazil was $1,591,986$ tons in 2018, grown in an area of 74,475 hectares. Total grapes yielded $51.39 \%$ production of wine, juice and derivatives. Rio Grande do Sul is the largest producer of the fruit, with an estimated production in 2019 of 666,423 tons, followed by Pernambuco and São Paulo (ANUÁRIO BRASILEIRO DE HORTI \& FRUTI, 2020).

Juice elaboration emerges as an alternative for the use of grapes due to its easy manufacturing process, organoleptic aspects and nutritional value
(RIZZON \& MENEGUZZO, 2007). In Brazil, the consumption of grape juice was 1.23 liters per person in 2017 (EMBRAPA, 2019). Among the vine cultivars intended for juice production in Brazil, 'BRS Magna' was released as an alternative to improve the color, sweetness and flavor of the produced grape juice (RITSCHEL et al., 2012), these characteristics may be favored by using the appropriate rootstock.

The use of adequate rootstocks can be an alternative strategy to induce resistance to soil-borne pests and diseases (MUROLO \& ROMANAZZI, 2014), enhance tolerance to abiotic stresses (TSEGAY et al., 2014), biochemistry (SOMKUWAR et al., 
2014) mineral nutrition (KODUR et al., 2011) and physiology (COOKSON \& OLLAT, 2013).

An obstacle for obtaining successful results with use grafting is the compatibility between the scion and the rootstock. The compatibility is defined as the establishment of a successful graft union resulting in a proper functioning composite, grafted plant (GOLDSCHMIDT, 2014). In practice, incompatible combinations can be costly for nurseries and replacing young vines that have declined in the field is expensive. Unfortunately, there is not much published definitive information on these issues (HERNANDES \& MARTINS, 2010).

In search of the ideal combination between rootstock and scion for juice production, This study evaluated the compatibility of the rootstock and the initial development of 'BRS Magna' grafted in different rootstocks.

The plant materials used in these experiments were obtained from Germplasm Bank Embrapa Products - Office Canoinhas-Santa Catarina, Brazil. One-year-old shoots of seventeen grapevine rootstocks were harvested in stage of dormancy and adequate sanitary condition, which were as it follows: 'Paulsen 1103', 'R99', 'R110', 'Gravesac', '101-14 MGT', '3309 Couderc', '420A', 'Solferino', 'SO4', 'Kober 5BB', 'IAC 766 Campinas', 'Freedom', 'Harmony', 'VR043-43', 'Salt Creek', 'IAC 572 Jales' and 'IAC 313 Tropical'. The cultivar used as scion was "BRS Magna". Shoots of rootstock were pre-cut in $30 \mathrm{~cm}$ and for scion with one meter.

Grafting was carried out in the experimental area of the Universidade Tecnológica Federal do Paraná - Campus Pato Branco in August 2018. Prior to the grafting, the plant material (rootstock and scion) was submitted to disinfestation through immersion in $1 \%$ sodium hypochlorite solution for $10 \mathrm{~min}$ then, it was rinsed in running water, followed by sprinkling with $70 \%$ alcohol. After disinfestation, the pre-cut rootstocks were prepared for grafting. Therefore, buds were removed, and a cross section was performed in the base of the cutting to increase the contact area with AIB, after forcing. Also, the upper part was cut about three centimeter above the last buds. In relation to the scion, a cut was realized $3 \mathrm{~cm}$ below and above of the buds. The wedge graft technique was utilized. Grafts were tied with Buddy Tape ${ }^{\circledR}$ to hold he grafting site and covered with Rebwachs W.F ${ }^{\circledR}$ wax melted at $65{ }^{\circ} \mathrm{C}$. Afterward, they were wrapped in newspaper and placed in pots with 20 $\mathrm{cm}$ of water and kept in forcing ventilation chamber, at a temperature of $19^{\circ} \mathrm{C}$ for 21 days, in the dark.
After forcing, the base of the grafts were washed and dipped in a solution of indolebutyric acid (IBA) $2000 \mathrm{mg} \mathrm{L}^{-1}$ for five seconds. Immediately after IBA application, the grafts were planted in $3 \mathrm{~L}$ pots containing commercial substrate and kept in a greenhouse with approximate temperature of $25^{\circ} \mathrm{C}$ and drip irrigation system for three minutes ( 0 - 40 days of development) and four minutes (40 - 120 days of development) every four hours, with a flow rate of $2 \mathrm{~L} /$ day per pot. Two applications of nutrient solution and one application of mancozeb $2 \mathrm{~g} / \mathrm{L}$ were carried out.

The experiment was set in a randomized block design with seventeen different rootstocks, each one constitutes a difference of treatment. Four replicates were used per treatment, with 15 grafts in each plot.

At 120 days in the greenhouse, the percentage of grafts survival was analyzed, and posteriorly five plants per treatment of each block were used for destructive analysis, in which the following were analyzed: the length of shoot and main roots; number of main roots and leaves per plant and the leaf area, determined through leaf area electronic integrator (LI-COR 3100). The plant parts were dried at $60{ }^{\circ} \mathrm{C}$, separately, and after drying, they were weighed.

The data were initially subjected to the Shapiro-Wilk test to verify the normality and to the Oneillmathews test to verify the homogeneity of variances. All variables met the assumptions and were submitted to analysis of variance and means were grouped by the Scott Knott's test $(p \leq 0.05)$. All the statistical analyses were carried in R language.

The percentage of survival ranged from $0 \%$ to $98.33 \%$, and the rootstock were grouped into three distinct groups (Table 1). The rootstocks '10114 MGT', 'IAC 572 Jales', 'Harmony', 'Gravesac', '420 A', 'Kober 5BB', 'IAC 766 Campinas', 'SO4', '3309 Couderc', 'R99', 'Freedom' and 'Salt Creek' formed a group with greater grafts survival. However, 'VR043-43' showed 100\% mortality; consequently, all other parameters evaluated had zero value.

As for shoot length, with the exception of 'VR043-43', the rootstocks were grouped into a single group (Table 2). Regarding the number of leaves, rootstocks were grouped into two groups in which 'Solferino' and 'R110' showed the smallest number of leaves, thus also showed smaller leaf area. Two groups were formed for the leaf area. The rootstocks 'IAC 572 Jales', 'IAC 313 Tropical', 'Freedom', '3309 Couderc', 'SO4', 'Harmony', 'Kober 5BB', '101-14 MGT', 'IAC 766 Campinas' and 'Gravesac' were those that had the highest values of leaf area. The dry shoot mass showed the same behavior as the leaf area. 
Table 1 - Survival averages at 120 days after grafting for 'BRS Magna' cultivar on different rootstocks.

\begin{tabular}{|c|c|}
\hline Rootstocks & Survival (\%) \\
\hline '101-14MGT' & $98.33 \mathrm{a}^{*}$ \\
\hline 'IAC 572 Jales' & $93.33 \mathrm{a}$ \\
\hline 'Harmony’' & $91.67 \mathrm{a}$ \\
\hline 'Gravesac' & $88.33 \mathrm{a}$ \\
\hline ' $420 \mathrm{~A}$ ' & $83.34 \mathrm{a}$ \\
\hline 'Kober 5BB' & $83.34 \mathrm{a}$ \\
\hline 'IAC 766 Campinas' & $81.67 \mathrm{a}$ \\
\hline 'SO4’ & $81.67 \mathrm{a}$ \\
\hline '3309 Couderc' & $81.67 \mathrm{a}$ \\
\hline 'R99' & $80.00 \mathrm{a}$ \\
\hline 'Freedom' & $80.00 \mathrm{a}$ \\
\hline 'Salt Creek' & $78.33 \mathrm{a}$ \\
\hline 'Paulsen 1103' & $70.00 \mathrm{~b}$ \\
\hline 'Solferino' & $68.34 \mathrm{~b}$ \\
\hline 'IAC 313 Tropical' & $63.34 \mathrm{~b}$ \\
\hline 'R110' & $51.67 \mathrm{~b}$ \\
\hline 'VR043-43' & $0.00 \mathrm{c}$ \\
\hline
\end{tabular}

${ }^{*}$ Means followed by different letters differ by Scott-Knott test $(\mathrm{p} \leq 0.05)$.

For the root length, the genotypes were divided into two groups, and the rootstocks 'Freedom', 'IAC 572 Jales', 'Paulsen 1103', 'Harmony', 'Gravesac', 'IAC 313 Tropical' and
'3309 Couderc' were those that showed greater lengths of primary roots. The other rootstocks were grouped in the second group. In the same way, the number of primary roots presented two distinct

Table 2 - Length of shoot (LS) and roots (LR), number of roots (NR) and leaves (NL), leaf area (LA) and dry mass of root (DMR) and shoot (DMS) at 120 days after grafting of 'BRS Magna' cultivar on different rootstocks.

\begin{tabular}{|c|c|c|c|c|c|c|c|}
\hline Rootstocks & $\mathrm{LS}(\mathrm{cm})$ & $\mathrm{LR}(\mathrm{cm})$ & NR & NL & $\mathrm{LA}\left(\mathrm{cm}^{2}\right)$ & DMR (g) & DMS (g) \\
\hline 'Paulsen 1103' & $65.79 \mathrm{a}^{*}$ & $58.71 \mathrm{a}$ & $13.94 \mathrm{a}$ & $13.86 \mathrm{a}$ & $765.51 \mathrm{~b}$ & $5.78 \mathrm{c}$ & $5.56 \mathrm{~b}$ \\
\hline 'IAC 572 Jales' & $81.38 \mathrm{a}$ & $62.23 \mathrm{a}$ & $15.61 \mathrm{a}$ & $16.50 \mathrm{a}$ & $1285.11 \mathrm{a}$ & $11.86 \mathrm{a}$ & $11.96 \mathrm{a}$ \\
\hline 'IAC 766 Campinas' & $71.20 \mathrm{a}$ & $39.90 \mathrm{~b}$ & $12.79 \mathrm{a}$ & $15.11 \mathrm{a}$ & $1030.31 \mathrm{a}$ & $7.52 \mathrm{~b}$ & $8.72 \mathrm{a}$ \\
\hline 'IAC 313 Tropical' & $95.25 \mathrm{a}$ & $55.25 \mathrm{a}$ & $18.58 \mathrm{a}$ & $17.17 \mathrm{a}$ & $1246.57 \mathrm{a}$ & $14.86 \mathrm{a}$ & $11.57 \mathrm{a}$ \\
\hline 'Gravesac' & $68.88 \mathrm{a}$ & $55.25 \mathrm{a}$ & $11.38 \mathrm{~b}$ & $16.13 \mathrm{a}$ & $1015.29 \mathrm{a}$ & $8.65 \mathrm{~b}$ & $8.09 \mathrm{a}$ \\
\hline 'R99' & $68.04 \mathrm{a}$ & $37.17 \mathrm{~b}$ & $10.96 \mathrm{~b}$ & $15.54 \mathrm{a}$ & $684.29 \mathrm{~b}$ & $3.42 \mathrm{c}$ & $3.66 \mathrm{~b}$ \\
\hline 'Freedom' & $70.29 \mathrm{a}$ & $70.86 \mathrm{a}$ & $17.54 \mathrm{a}$ & $15.56 \mathrm{a}$ & $1206.02 \mathrm{a}$ & $9.81 \mathrm{~b}$ & $10.96 \mathrm{a}$ \\
\hline 'Salt Creek' & $57.71 \mathrm{a}$ & $44.54 \mathrm{~b}$ & $9.21 \mathrm{~b}$ & $12.73 \mathrm{a}$ & $691.38 \mathrm{~b}$ & $2.51 \mathrm{c}$ & $5.27 \mathrm{~b}$ \\
\hline 'Harmony’ & $81.46 \mathrm{a}$ & $57.81 \mathrm{a}$ & $18.29 \mathrm{a}$ & $14.46 \mathrm{a}$ & $1141.61 \mathrm{a}$ & $13.07 \mathrm{a}$ & $9.84 \mathrm{a}$ \\
\hline '3309 Couderc' & $65.13 \mathrm{a}$ & $54.06 \mathrm{a}$ & $13.19 \mathrm{a}$ & $16.81 \mathrm{a}$ & $1175.73 \mathrm{a}$ & $9.42 \mathrm{~b}$ & $10.60 \mathrm{a}$ \\
\hline 'Solferino' & $50.34 \mathrm{a}$ & $31.67 \mathrm{~b}$ & $10.08 \mathrm{~b}$ & $9.50 \mathrm{~b}$ & $572.05 \mathrm{~b}$ & $3.14 \mathrm{c}$ & $4.34 \mathrm{~b}$ \\
\hline 'R110’ & $42.88 \mathrm{a}$ & $42.38 \mathrm{~b}$ & $8.13 b$ & $8.37 \mathrm{~b}$ & $389.00 \mathrm{~b}$ & $2.03 \mathrm{c}$ & $2.65 \mathrm{c}$ \\
\hline '420 A' & $64.05 \mathrm{a}$ & $37.55 \mathrm{~b}$ & $8.65 \mathrm{~b}$ & $13.80 \mathrm{a}$ & $691.59 \mathrm{~b}$ & $3.06 \mathrm{c}$ & $4.93 \mathrm{~b}$ \\
\hline '101-14MGT' & $73.19 \mathrm{a}$ & $40.50 \mathrm{~b}$ & $21.99 \mathrm{a}$ & $15.55 \mathrm{a}$ & $1056.12 \mathrm{a}$ & $12.20 \mathrm{a}$ & $9.01 \mathrm{a}$ \\
\hline 'SO4' & $87.16 \mathrm{a}$ & $47.82 \mathrm{~b}$ & $14.39 \mathrm{a}$ & $18.08 \mathrm{a}$ & $1172.07 \mathrm{a}$ & $9.12 \mathrm{~b}$ & $10.13 \mathrm{a}$ \\
\hline 'Kober 5BB' & $76.65 \mathrm{a}$ & $44.25 \mathrm{~b}$ & $16.21 \mathrm{a}$ & $14.33 \mathrm{a}$ & $1100.80 \mathrm{a}$ & $6.39 \mathrm{c}$ & $7.64 \mathrm{a}$ \\
\hline
\end{tabular}

${ }^{*}$ Means followed by different letters in the column differ by Scott-Knott test $(\mathrm{p} \leq 0.05)$. 
groups, where the rootstocks '101-14 MGT' 'IAC 313 Tropical', 'Harmony', 'Freedom', 'Kober 5BB', 'IAC 572 Jales', 'SO4', 'Paulsen 1103', '3309 Couderc' and 'IAC 766 Campinas' showed the highest number of roots. However, for root dry mass, the rootstocks 'IAC 313 Tropical', 'Harmony', '101-14 MGT', 'IAC 572 Jales', 'Freedom', '3309 Couderc', 'SO4', 'Gravesac', 'IAC 766 Campinas' showed the best results.

Principal component analysis showed that 'IAC Tropical' and 'SO4' rootstocks were those with the highest vigor in relation to initial shoot growth. The other hand, 'IAC Jales', 'Harmony', '3309 Couderc' and 'Gravesac' presented the best balance between initial shoot growth on and root development. The rootstock 'Freedom' was the one that had the greatest initial development of roots. 'Solferino', 'R99' and '420A' presented mediumlow vigor, with low initial root development. 'Paulsen 1103' and 'Salt Creek' presented medium vigor, with intermediate root development (Figure $1)$.

Results showed that the percentage of grafts survival varied according to the rootstock. Similar results were obtained with 'Syrah' and 'Chardonnay' grafted on different rootstocks, which can be attributed to the different levels of welding of the grafts, which in some cases are quite irregular. These cultivars, when grafted on '420A', showed low grafts survival (REGINA et al., 2012), a result different from that obtained in this research. However, the combination 'BRS Magna'/'420A', caused minimal development of the seedling, which can characterize an incompatibility.

The 'BRS Magna' presented different initial development according to the rootstock. The evaluation of the vigor that the rootstock provides to the canopy is necessary for selecting the ideal combination and the production techniques to be adopted. More vigorous rootstocks are more suitable

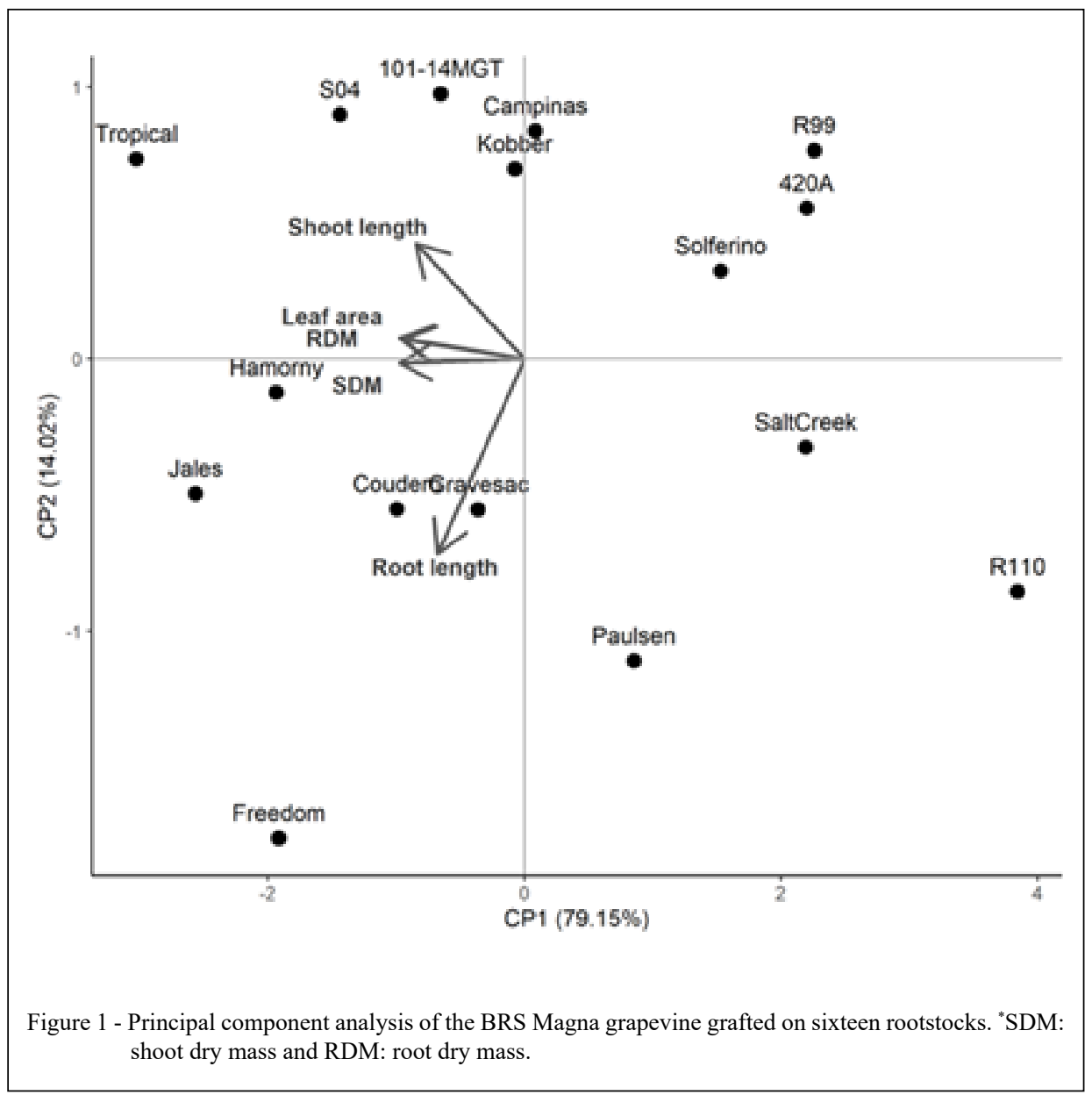

Ciência Rural, v.51, n.7, 2021. 
for producing regions that have low soil fertility, since they have a greater capacity of absorption and transport of water, mineral salts and greater production of substances that promote the vegetative growth on the plants (HARTMANN \& KESTER, 1990; LEÃO et al., 2011), or sites where more than one crop is cultivated per year. In these cases, low vigor rootstocks do not present satisfactory vegetative growth, resulting in lower production of the vines (LEÃO et al., 2011).

Adequate vigor should be sought, so that its excess or lack will not be translated into reduced productivity (ALVARENGA et al., 2002; BORGHEZAN et al., 2011). The difference in vigor of the cultivar is not only influenced by the rootstock, but also by the vigor of the scion genotype. Cultivars considered vigorous showed higher vegetative growth when compared to low vigor cultivars, grafted on the same graft (CLÍMACO et al., 2003). The cultivar 'BRS Magna' has medium vigor (RITSCHEL et al., 2012), which may justify the lower initial development when grafted on 'Paulsen 1103'.

The 'VR043-43' rootstock shows incompatibility of grafting of woody cuttings. As this hybrid originates from the Vitis rotundifolia Michx x Vitis vinifera L. cross, there is genetic incompatibility of the species Vitis rotundifolia Michx for use as rootstock of commercial vine cultivars (TORREGROSA \& BOUQUET, 1995). In addition, there is great difficulty in rooting through woody cuttings, probably because of the anatomical characteristics of this rootstock, which influence the arrangement of fibers in the secondary phloem, the permanence of fibers in the primary phloem, narrow rays and small vessel elements, as well as the high acid concentration and phenolics near the places that could originate the adventitious roots (MAYER et al., 2006). One solution to consider in this study would be the use of semiwoody or herbaceous cuttings that root more easily than woody cuttings (GOODE JÚNIOR \& LANE, 1983).

In conclusion, the 'BRS Magna' when grafted on rootstocks 'IAC Tropical', 'SO4' and '101-14 MGT' showed the highest initial development rates. The 'BRS Magna' grafted on 'R99', 'R110' and '420A' showed the lowest initial development. Hybrid rootstocks originating from crosses with Vitis berlandieri Planch showed low root development. The 'VR043-43' rootstock shows incompatibility of woody cuttings grafting in the production of seedling through the technique of wegde grafting.

\section{ACKNOWLEDGEMENTS}

The authors would like to thank Universidade Tecnológica Federal do Paraná for the structure and materials, the Coordenação de Aperfeiçoamento de Pessoal de Nível Superior (CAPES) for financial support, for grating the scholarship to Chaiane Renata Grigolo, Rafael Henrique Pertille and Silvia Scariotto, the Conselho Nacional de Desenvolvimento Científico e Tecnológico $(\mathrm{CNPq})$ for grating financial resources to Ester Provensi Santos and Kelvin Cristhian Campos Takeshita, the Embrapa for the plant material and the agronomist engineer MsC. Lari Maroli for the assistance in the accomplishment of the grafting.

\section{DECLARATION OF CONFLICT OF INTEREST}

The authors declare no conflict of interest. The founding sponsor had no role in the design of the study; in the collection, analyses, or interpretation of data; in the writing of the manuscript, and in the decision to publish the results.

\section{AUTHORS' CONTRIBUTIONS}

The authors contributed equally to the manuscript.

\section{REFERENCES}

ALVARENGA, A. A. et al. Influence of rootstock on the growth and production of the 'Niágara rosada' vine cultivar (Vitis labrusca L. $\mathrm{x}$ Vitis vinifera L.), under acidic soil conditions. Ciência e Agrotecnologia, Edição Especial, p.1459-1464, 2002.

ANUÁRIO BRASILEIRO DE HORTI \& FRUTI 2020. Editora Gazeta, 2020. Available from: < http://www.editoragazeta.com. br/produto/anuario-brasileiro-de-horti-fruti-2020/>. Accessed: Jul. 03, 2020

BORGHEZAN, M. et al. Vegetative and productive behavior of grapevines and composition of grapes in São Joaquim, Santa Catarina, Brazil. Pesquisa Agropecuária Brasileira, v.46, n.4, p.398-405, 2011. Available from: $<\mathrm{http} / /$ www.scielo.br/scielo.php?script $=\mathrm{sci}$ arttext\&pid=S0100-204X2011000400009\&lng=pt\&tlng=pt $>$. Acessed: May, 10, 2019. doi: 10.1590/S0100-204X2011000400009.

CLÍMACO, P. et al. Efeito da casta e do porta-enxerto no vigor e na produtividade da videira. Ciência e Técnica Vitivinícola, v.18, n. 1, p.1-14, 2003.

COOKSON, S. J.; OLLAT, N. Grafting with rootstocks induces extensive transcriptional re-programming in the shoot apical meristem of grapevine. BMC Plant Biol, v.13, p.147, 2013. Available from: <https://bmcplantbiol.biomedcentral.com/ articles/10.1186/1471-2229-13-147>. Accessed: Apr. 05, 2019. doi: 10.1186/1471-2229-13-147.

EMBRAPA - EMPRESA BRASILEIRA DE PESQUISA AGROPECUÁRIA (2019) Inteligência e Mercado de Uva e Vinho. Brasília, Embrapa. Available from: $<$ https://www.embrapa. br/cim-inteligencia-e-mercado-uva-e-vinho/a-viticultura-nobrasil>. Accessed: Aug. 05, 2019.

GOLDSCHMIDT, E.E. The evolution of fruit tree productivity: a review. Econ. Bot., v.67, p. 51-62, 2014. Available from: <http://

Ciência Rural, v.51, n.7, 2021. 
dx.doi.org/10.1007/s12231-012-9219-y>. Accessed: Aug. 05, 2019.

GOODE JUNIOR, D. Z.; LANE, R. P. Rooting leafy muscadine grape cuttings. HortScience, v.18, n.6, p.944- 946, 1983.

HARTMANN, H.T.; KESTER, D. E. Propagación de plantas: principios y practicas. México: Continental, 1990. p.760.

HERNANDES, J. L.; MARTINS, F. P. Importância do uso de porta-enxertos na viticultura. In: BUENO, S. C. S. (Coord.). Vinhedo paulista. 2010. Available from: $<$ http://www.infobibos. com/Artigos/2010_2/PortaEnxertos/Index.htm>. Accessed: Jun. 04. 2019.

KODUR, S. et al. Uptake, transport, accumulation and translocation of potassium in grapevine rootstocks (Vitis). Journal of Grapevine Research. v.50, p.145-149, 2011. Available from: $<$ https://ojs.openagrar.de/index.php/VITIS/article/view/4082>. Accessed: Mar. 24, 2019.

LEÃO, P. C. S. et al. Production and quality of table grapes 'Sugraone' on different rootstocks in the São Francisco River Valley. Ciência Rural, v.9, p.1526-1531, 2011. Available from: $<$ http://www.scielo.br/scielo.php?script=sci_arttext\&pid=S010384782011000900006\&lng=pt\&tlng=pt $>$. Accessed: Mar. 25, 2019. doi: 10.1590/S0103-84782011000900006.

MAYER, J. L. S. et al. Rooting ability of four Vitis L. (Vitaceae) cultivar cuttings related to anatomy. Acta Botanica Brasilica, v.20, n.3, 563-568, 2006. Available from: <http://www.scielo.br/scielo. php?script=sci_arttext\&pid=S0102-33062006000300006\&ln $\mathrm{g}=\mathrm{pt \& tlng}=\mathrm{pt}>$. Accessed: Jun. 11, 2019. doi: 10.1590/S010233062006000300006

MUROLO, S.; ROMANAZZI, R. Effects of grapevine cultivar, rootstock and clone on esca disease. Australasian Plant Pathology, v.43, n.2, p.215-221, 2014. Available from: <https:// link.springer.com/article/10.1007\%2Fs13313-014-0276-9>. Accessed: May, 14, 2019. doi: 10.1007/s13313-014-0276-9.
REGINA, M. A. et al. Propagation of vitis spp. by bench grafting table using different rootstocks and auxins. Revista Brasileira de Fruticultura, v.34, n.3, p.897-904, 2012. Available from: $<\mathrm{http}: / /$ www.scielo.br/scielo.php?script=sci arttext\&pid=S010029452012000300032\&lng=pt\&tlng=pt $>$. Accessed: Jun. 5, 2019. doi: $10.1590 / \mathrm{s} 0100-29452012000300032$.

RITSCHEL, P. et al. 'BRS Magna': Nova cultivar de uva para suco com ampla adaptação climática. Comunicado Técnico Embrapa, 2012. Available from: <https://ainfo.cnptia.embrapa.br/digital/ bitstream/item/71803/1/cot125.pdf $>$. Accessed: Mar. 07, 2019.

RIZZON, L. A.; MENEGUZZO, J. Suco de uva. Comunicado Técnico Embrapa. 2007. Available from: <https://ainfo.cnptia. embrapa.br/digital/bitstream/item/11888/2/00081370.pdf $>$. Accessed: Aug. 04, 2019.

SOMKUWAR, R. G. et al. Rootstocks influence the growth, biochemical contents and disease incidence in Thompson Seedless grapevines. British Journal of Applied Science \& Technology, v.4, p.1030-1041, 2014. Available from: <http:// www.sciencedomain.org/abstract/2849>. Accessed: Mar. 13, 2019. doi: 10.9734/BJAST/2014/4450.

TORREGROSA, L.; BOUQUET, A. In vitro propagation of Vitis $\mathrm{x}$ Muscadinia hybrids by microcuttings or axillary budding. Vitis, v.34, n.4, p.237-238, 1995.

TSEGAY, D. et al. Responses of grapevine rootstocks to drought stress. International Journal of Plant Physiology and Biochemistry, v.6, n.1, p.1-6, 2014. Available from: <https://academicjournals.org/ journal/IJPPB/article-abstract/AA681DF42863>. Accessed: Mar. 09, 2019. doi: 10.5897/IJPPB2013.0199.

ZANUS, M. C. Panorama da vitivinicultura brasileira. Anais... XV Congresso Latino-Americano de Viticultura e Enologia. 2015. Available from: $<$ https://www.embrapa.br/busca-de-publicacoes/-/ publicacao/1033264/panorama-da-vitivinicultura-brasileira $>$. Accessed: Mar. 14, 2020. 